\title{
Correction to: Topological approach to generalized soft rough sets via near concepts
}

\author{
Muhammad Irfan Ali $^{1}$ (D) Mostafa K. El-Bably ${ }^{2}$ (D) El-Sayed A. Abo-Tabl ${ }^{3,4}$ (D)
}

Published online: 10 February 2022

(C) Springer-Verlag GmbH Germany, part of Springer Nature 2022

\section{Correction to: Soft Computing \\ https://doi.org/10.1007/s00500-021-06456-z}

The originally published article the reference El-Bably MK, Ali MI, Abo-Tabl EA (2021) was incorrectly published. The correct reference has been copied below.

El-Bably, MK, Ali, MI, Abo-Tabl, EA (2021) New topological approaches to generalized soft rough approximations with medical applications, Journal of Mathematics, vol. 2021, Article ID 2559495, 16 pages, 2021. https://doi.org/10.1155/2021/2559495

The original article has been corrected.

Publisher's Note Springer Nature remains neutral with regard to jurisdictional claims in published maps and institutional affiliations.

The original article can be found online at https:// doi.org/10.1007/s00500-021-06456-z.

Muhammad Irfan Ali

mirfanali13@yahoo.com

Mostafa K. El-Bably

mkamel_bably@yahoo.com

El-Sayed A. Abo-Tabl

a.adotabl@qu.edu.sa

1 Mathematics Department, Islamabad Model College for Boys, F-10/3, Islamabad, Pakistan

2 Mathematics Department, Faculty of Science, Tanta University, Tanta, Egypt

3 Mathematics Department, Faculty of Science, Assiut University, Assiut, Egypt

4 Mathematics Department, College of Science and Arts, Methnab, Qassim University, Buridah, Saudi Arabia 